\author{
Agnieszka Świętek, Wiktor Osuch \\ Uniwersytet Pedagogiczny \\ im. Komisji Edukacji Narodowej \\ w Krakowie
}

\title{
Wybrane problemy mniejszości narodowych a idea społeczeństwa obywatelskiego w Unii Europejskiej
}

Europa jako kontynent, z klasycznego, geograficzno-fizycznego, punktu widzenia nie istnieje. Jest jedynie dużym półwyspem azjatyckim. Z każdego innego punktu widzenia można by się pokusić o stwierdzenie, że Europa jest najważniejszym spośród wszystkich kontynentów naszego globu. Do podejścia takiego uprawnia jej bogactwo kulturowe, społeczne, etniczne, religijne, jej źródłowy charakter dla współczesnych kultur wielu innych części globu oraz pełniona rola centrum myśli innowacyjnej i naukowej kiedyś i dziś.

Idea zjednoczonej Europy nie jest tworem współczesności. Najpełniej realizowana była ona w okresie średniowiecza. Fundamentem ówczesnej jedności narodów, która miała charakter religijno-kulturowy, było chrześcijaństwo, a jednym z podstawowych wyznaczników jedności narodów był wspólny język. W średniowiecznej Europie w powszechnym użyciu były, jak dziś, języki narodowe, lecz oficjalnym językiem chrześcijaństwa była łacina (Siewierski 2006). Posługiwały się nią rzesze duchownych na całym obszarze kontynentu. Stała się ona przez to uniwersalnym dla całego kontynentu językiem nauki i myśli filozoficznej. Wyrazem owego wspólnego języka było odprawianie mszy świętej w języku łacińskim we wszystkich europejskich kościołach. Chrześcijaństwo wytworzyło z narodów europejskich wspólnotę odczuwalną w codziennym życiu mieszkańców. Kościół był wyznacznikiem wielu praktykowanych zwyczajów (oczywiście w różnych regionalnych odmianach) przez wszystkie narody. I tak wspólne dla wszystkich Europejczyków były: napomnienia dla wiernych, sposób chowania zmarłych, wspomagania ubogich, poszanowania władcy, potępienia cudzołóstwa, szacunku wobec osób wyżej urodzonych (Siewierski 2006), te same daty świąt religijnych i postów. Chrześcijaństwo jednoczyło narody europejskie praktycznie na wszystkich płaszczyznach życia. Było wyznacznikiem jednolitych w całej Europie stylów architektonicznych, sztuki sakralnej i świeckiej. Ujednoliciło, a w zasadzie wprowadziło, programy nauczania gramatyki, retoryki, dialektyki, muzyki, arytmetyki, geometrii oraz astronomii, a od XII wieku upowszechniło studia uniwersyteckie (Siewierski 2006). Niezwykle istotny był również wpływ religii na ustrój polityczny i powiązany z nim porządek społeczny. Wszędzie dominowała zasada hierarchiczności, zarówno na najwyższych, jak i lokalnych (miejskich) szczeblach władzy. Ludność miała wyznaczone zadania, które porządkowały jej pozycję społeczną i materialną, czego świetnym przykładem był stan rycerski czy stan mieszczański. Ówczesna jedność Europy, nie oparta na umowach międzynarodowych (pod względem politycznym zależna od wpływów kościoła), istniała w codziennym życiu ludności, a zatem opierała się na wspólnej kulturze i jednakowych standardach cywilizacyjnych. Z racji konkurencyjności 
silnych ośrodków plany stworzenia jednego państwa europejskiego na wzór cesarstwa rzymskiego nie były jednak możliwe do zrealizowania (Siewierski 2006).

Współczesna wizja Europy zjednoczonej nabierała kształtów po I wojnie światowej, kiedy to powstała idea Stanów Zjednoczonych Europy. Jej źródłem był, jak się wkrótce okazało nie bezpodstawny, strach przed kolejną wojną. Po II wojnie światowej nie było już żadnych wątpliwości - narody europejskie bez umów międzynarodowych narażone były na klęskę zarówno społeczną, jak i gospodarczą. Pomimo zaprzestania walk zbrojnych, sytuacja wewnątrz Europy podnoszącej się z gruzów wojny wcale nie rokowała świetlanej przyszłości. Podzielona na wschód i zachód murem berlińskim społeczność europejska coraz bardziej się od siebie oddalała. Nawet rozwijające się kraje zachodnioeuropejskie, w latach 50. i 60. XX wieku nie były w stanie pojedynczo konkurować z dobrze rozwiniętą gospodarką Stanów Zjednoczonych (które dodatkowo wzbogaciła wojna w Europie). Pierwszym krokiem w tworzeniu dzisiejszej Unii Europejskiej było powstanie Europejskiej Wspólnoty Węgla i Stali, a zatem organizacji ściśle gospodarczej (Niżnik 2006).

Wspólnota ewoluowała od tamtej pory na wielu płaszczyznach. Nadal jednak pozostaje ona organizacją o charakterze głównie gospodarczym. W wymiarze politycznym integracja jest dużo słabiej posunięta, a akceptacja wprowadzanych kolejnych przepisów z trudem przychodzi wielu krajom. Zupełnie inaczej wygląda natomiast integracja kulturowa, na której przecież tak silnie opierała się jedność Europy w średniowieczu.

Współcześnie wspólna polityka unijna ogranicza się do „programów w oświacie, nauce i aktywności artystycznej oraz wspólnej polityce audiowizualnej” (Siewierski 2006, s. 20). Brak wyraźnej wspólnoty kulturowej, która jest wyrazem więzi społecznej, winien być głównym obiektem zainteresowania w dalszych planach rozwoju Unii. Bez więzi tej, gdy wygasną interesy ekonomiczne, może się okazać, że idea integracji staje się fikcją.

Aby wytworzyła się owa więź, musimy uporać się najpierw z głęboko zakorzenionymi w nas stereotypami i uprzedzeniami etnicznymi oraz narodowymi. Wtedy to można dopiero spróbować mówić o prawdziwej Unii ludzi, ludzi, których jednoczy tożsamość europejska.

C. Fridrich (2007) przytacza jeden ze sposobów rozumienia tożsamości jako: „mentalnej struktury, która pomaga w orientacji poprzez łączenie kategorii samego siebie i kogoś innego w związek”, konkludując, że: „do rozróżnienia dochodzi poprzez wytyczenie granic” (Fridrich 2007, s. 8). Poczucie tożsamości narodowej, pomimo faktu integracji gospodarczej i w dużej mierze również politycznej, egzystencji w jednoczącej się Europie, oraz intensywnej współcześnie globalizacji (a może właśnie dzięki niej!) nadal jest bardzo silne wśród Europejczyków, a według niektórych badaczy, nawet rośnie w siłę. Europejczycy nadal czują silne przywiązanie do swego narodu, przy jednoczesnym braku tworzenia się kulturowej tożsamości ogólnoeuropejskiej. Z badań empirycznych wynika, że podkreślają oni w swoim stosunku do zjednoczonej Europy wspólne wartości, takie jak pokojowe rozwiązywanie konfliktów, ochrona praw mniejszości czy dobrobyt (Halfman 2006). Są one własnościami uniwersalnymi, które nie tworzą owej wcześniej wspomnianej „granicy”, a zatem nie dają Europie odrębności. Wartości te przecież równie dobrze mogłyby być kultywowane bez wspólnoty europejskiej, a charakterystyczne są nie tylko dla niej.

Obok kwestii braku wspólnej tożsamości ogólnonarodowej w Europie, bardzo ważnym zagadnieniem w rozważaniach na temat integracji europejskiej jest rozłączanie się w ostatnich czasach pojęć narodu i państwa (Niżnik 2006). Otwieranie granic czy zanik państwowej waluty, to tylko przykłady słabnącego znaczenia państwa w dobie integracji. Osłabienie suwerenności państwowej, jakie Unii zarzucają eurosceptycy nie przekłada się jednak na osłabienie więzi narodowych. Okazuje się, że rozluźnieniu ulegają tylko sztywne ramy państwowe, 
a naród, jako złączona tożsamością społeczność, istnieje nadal. Sukcesywne ograniczanie suwerenności państw na różnych płaszczyznach spowoduje ich zdecydowane osłabienie w stosunku do rosnącego w siłę organizmu unijnego. Zmieni się przez to charakter Unii, która będzie dążyć ku wspólnocie narodów, a nie wspólnocie państw. Miejmy nadzieję, że narodów tworzących społeczeństwo obywatelskie.

Społeczeństwo obywatelskie, zgodnie z encyklopedią politologii, zacytowaną w swej pracy przez Chodubskiego (2006), to „,społeczeństwo charakteryzujące się zbiorową samoświadomością, ukierunkowaną na urzeczywistnianie społeczno-politycznego i ekonomicznego wspólnego dobra" (Chodubski 2006, s. 65). Społeczeństwo takie charakteryzuje postawa, życiowa, która ukierunkowana jest na realizację ideałów „sprawnej organizacji, praworządności i unijności” opartych na „wolności, samorządności, tolerancji”, a także „obywatelskości”, rozumianej jako aktywny udział społeczeństwa w życiu publicznym, a w szczególności w podejmowaniu decyzji i wygłaszaniu opinii (Chodubski 2006). Społeczeństwo to jest zbiorem jednostek wzajemnie szanujących swe różne reakcje, aspiracje, opory i odrębność, posiadającym rodzaj kultury obywatelskiej, w której ważnymi wartościami są: zaufanie, lojalność, solidarność, więzi regionalne i wreszcie tożsamość indywidualna i zbiorowa (Chodubski 2006). Wspomniany autor wymienia ponadto dziewięć wyznaczników wartości owej społeczności, które w naszych rozważaniach są zarazem punktami do wypełnienia przez Europejczyków w drodze do integracji. Zalicza do nich między innymi uznanie praw człowieka za ważniejsze od praw państwowych, tolerancję wobec różnych systemów wartości, realizację idei harmonijnego współistnienia, akceptację migracji i integracji oraz troskę o pokój i bezpieczeństwo (Chodubski 2006). Społeczeństwo obywatelskie, które jest przyszłością zintegrowanego społeczeństwa europejskiego będzie zatem łączyć w sobie przywiązanie, szacunek do tradycji i uniwersalnych wartości z otwartością na inność i rozwój.

Jak daleko nam do stania się takim społeczeństwem? Ile potrwa jeszcze integracja, jeśli ma być integracją społeczną? Jaką miarą można określić nie czas, a dystans pomiędzy narodami europejskimi, odległość, jaka dzieli jednego z nas od zrozumienia i docenienia drugiego? Tak jak w przysłowiu, że prawdziwych przyjaciół poznaje się w biedzie, tak i gotowość do tworzenia wspólnoty wśród ludzi wyraża się ich gotowością do poświęcenia, zrezygnowania z własnego dobra na rzecz innych.

Taka wspólnota wytwarza się we współczesnej Europie na poziomie gospodarczym, gdzie ze wspólnych unijnych pieniędzy wspomagane są kraje biedniejsze, najczęściej nowoprzyjęte. Innym sposobem ,pomiaru” stopnia integracji społecznej w Unii jest stosunek państw członkowskich do zamieszkujących w nich mniejszości narodowych i etnicznych.

W myśl naszych wcześniejszych rozważań Unia Europejska w przyszłości stać się ma unią nie państw, a narodów, których członkowie stworzą społeczeństwo obywatelskie. W tym celu wszyscy członkowie Unii powinni dążyć do wzajemnej równości, którą da się osiagnąć, jedynie wyzbywając się stereotypów i uprzedzeń oraz pomagając narodom słabiej rozwiniętym w dorównywaniu do wysokiego poziomu, w imię społecznej solidarności. Tolerancja, przestrzeganie praw i pomoc mniejszościom narodowym i etnicznym stają się zatem wyznacznikami i wielkim sprawdzianem integracji dla krajów przez nie zasiedlanych.

\section{Stosunek do mniejszości narodowych i etnicznych miernikiem europejskiej integracji społecznej}

Zjawisko wielokulturowości zawsze było w Europie zjawiskiem naturalnym. Jedynie w wieku XIX i XX państwa narodowe próbowały sztucznie utrzymać jednolitość poprzez edukację, asymilację lub wręcz deportację czy eksterminację ,przybyszów”. W przeciągu tych dwóch 
wieków utrwaliło się w świadomości wielu Europejczyków przekonanie o zagrożeniu, jakie stwarza wielokulturowość dla suwerenności państw (Halfmann 2006). Dziś, gdy sztywne struktury państwa ulegają rozluźnieniu, a narody nie wydają się być przez to zagrożonymi, jedynymi barierami są bariery w ludzkich umysłach, których nie da się zaobserwować, lecz można o nich wnioskować na podstawie ich efektów.

Europa w wieku XXI wraca do swej tradycyjnej różnorodności etnicznej i narodowej. Zgodnie z różnymi szacunkami, mniejszości narodowe stanowią od 9,6\% do 16,2\% ludności Europy i zamieszkują od 8\% do 19,3\% jej powierzchni (Porębski 2006). Problemu akceptacji i praw mniejszości nie można zatem absolutnie traktować marginalnie. Niestety, dzieje się tak w wielu krajach unijnych, na co dowodem może być chociażby brak prowadzenia statystyk w tej dziedzinie przez wiele krajów. Danych takich nie gromadzi się w: Belgii, Danii, Holandii, Finlandii, Hiszpanii, Irlandii, Niemczech, a Francja i Grecja w ogóle nie uznają istnienia mniejszości na swoim terytorium. W większości z nich jako przyczynę tych luk statystycznych podawane jest prawo o ochronie informacji osobowych. Dane uzyskiwane z tych krajów maja jedynie charakter szacunkowy, a zebrane zostały przez wymuszenie Unii w postaci obowiązku przestrzegania Europejskiej Karty Języków Regionalnych lub Mniejszościowych, oraz Europejskiej Konwencji Ramowej o Ochronie Mniejszości Narodowych (Janusz 2006).

Problem Mniejszości Narodowych został podniesiony po II wojnie światowej w Karcie Narodów Zjednoczonych (1945) i nieco później w Powszechnej Deklaracji Praw Człowieka (1949). Najpełniej uniwersalne prawa każdego człowieka, oraz w szczególności prawo mniejszości narodowych do własnej kultury, języka i religii zawarła jednak Karta Praw Człowieka z roku 1966 (Chodubski 2006). Prawa mniejszości narodowych gwarantują również przepisy przyjęte przez Zgromadzenie Ogólne ONZ w Deklaracji praw należq̨cych do mniejszości narodowych lub etnicznych (1992). Ostatnią z najważniejszych organizacji, które poczyniły wiele w kierunku ochrony mniejszości jest Unia Europejska. W jej ramach, 10 listopada 1994 roku przyjęto Konwencję Ramową Rady Europy o Ochronie Mniejszości Narodowych, która określała ogólne zasady ochrony praw mniejszości, które państwa mają stopniowo wdrażać zmieniając swe ustawodawstwo. Warto zwrócić również uwagę na wymagania w kwestii praw mniejszości poprzez pryzmat rozszerzania Unii. Ustalone w roku 1993 kryteria kopenhaskie (potwierdzone Agendą 2000 w roku 1997) stały się podstawą oceny państw kandydujących do Unii przez Komisję Europejską, a zatem przestrzeganie praw mniejszości wśród nowych członków stało się jednym z kluczowych warunków ich akcesji (Rybczyńska 2006).

Jak już jednak niejednokrotnie w tym artykule wspomniano, skonstruowanie choćby najlepszego prawa nie wpłynie jednak na poglądy i odczucia, a te są kluczowe w kwestii akceptacji mniejszości w społeczeństwie. Dlatego też powołano w ramach Unii inne organizacje badające procesy społeczne. Jedną z nich, powstałą w 2007 roku, jest FRA (European Union Agency for Fundamental Rights), której podlega Europejskie Centrum Monitoringu Rasizmu i Ksenofobii (EUMC). Owocem pierwszego roku pracy EUMC był raport dotyczący rasizmu i ksenofobii w krajach członkowskich UE (Report on racism and xenophobia in the member states of the UE). Raport jest jednym z cennych źródeł informacji, które dają nam odpowiedź na stawiane w tej pracy pytanie o stopień integracji społecznej narodów w krajach Unii Europejskiej. Dokument ten zawiera informacje dotyczące rasizmu i dyskryminacji na trzech płaszczyznach: zatrudnienia, sektorów mieszkalnictwa i edukacji oraz statystyki dotyczące przemocy i przestępstw na tle rasowym. Najbardziej ewidentną i dającą się zmierzyć statystycznie dyskryminacją spośród opisanych w raporcie jest dyskryminacja na rynku pracy, którą statystycznie wyraża poziom bezrobocia wśród mniejszości w stosunku do poziomu bezrobocia w kraju, który mniejszość zamieszkuje. 
Zamieszczony poniżej wykres prezentuje wskaźnik pokazujący zależność pomiędzy wysokością stopy bezrobocia wśród mniejszości w stosunku do poziomu bezrobocia rodowitych mieszkańców danego kraju. Wskaźnik ten powstał przez podzielenie stopy bezrobocia wśród mniejszości przez stopę bezrobocia wśród ludności ogółem w danym kraju. Im wartość wyższa wskaźnika, tym gorzej, gdyż dysproporcje pomiędzy mniejszościami a resztą ludności są większe.

Zdecydowanie największe dysproporcje w tej kwestii występują w Belgii, gdzie stopa bezrobocia jest prawie pięć razy wyższa wśród mniejszości. Poziom prawie cztery razy wyższy występował w 2006 roku również w Luksemburgu. Wysokie dysproporcje zaznaczały się też w Finlandii oraz Holandii (około trzy razy wyższa stopa bezrobocia). Najmniejsze dysproporcje w stopie bezrobocia pomiędzy mieszkańcami rodzimymi a mniejszościami występowały w Czechach i Grecji.

Ryc. 1. Stosunek stopy bezrobocia wśród członków mniejszości narodowych do stopy bezrobocia wśród pozostałych mieszkańców w wybranych krajach UE

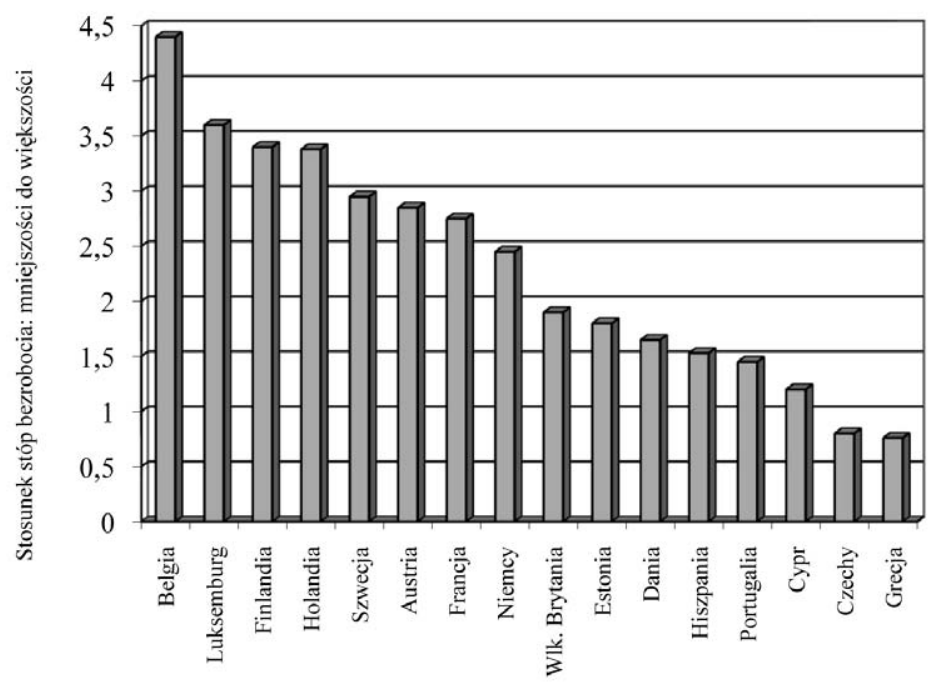

Źródło: opracowanie własne na podstawie: Report on racism and xenophobia in the member states of the UE, http://infoportal.fra.europa.eu/InfoPortal/publicationsFrontEndAccess.do?id=11016

Znacznie wyższa stopa bezrobocia wśród mniejszości narodowych nie wynika oczywiście tylko z winy samych państw. W dużej (jeśli nie dominującej) mierze przyczyniają się do tego przedstawiciele mniejszości, ze względu na brak kwalifikacji do pracy (wykształcenia, znajomości języka, doświadczenia) lub po prostu negatywny stosunek do pracy, jaki prezentują np. Romowie w Polsce, wśród których bezrobocie sięgało w 2006 roku średnio około 90\%. Statystyki te winny być jednak dla władz państw wyraźnym sygnałem do działania w zakresie poszukiwania przyczyn bezrobocia i przeciwdziałania mu, w szczególności, jeśli jego przyczyną jest dyskryminacja.

Raport EUMC wskazuje kilka przykładów ewidentnych dyskryminacji na rynku pracy. Jednym z nich jest niezatrudnianie przedstawicieli mniejszości tureckiej o tym samym wykształceniu i doświadczeniu w Niemczech, ze względu, jak tłumaczyli pracodawcy, na obawy przed zniechęceniem swoich klientów. W Szwecji 25\% pracodawców odrzuca w trakcie rekrutacji na pracowników osoby o arabsko brzmiących nazwiskach. W Czechach w 2005 roku romska 
kobieta starała się o pracę, odpowiadając na ogłoszenie przyklejone na witrynie sklepowej. Gdy zapytała o ofertę, została poinformowana, że ogłoszenie jest nieaktualne. Kolejna kobieta (nie-Romka), która weszła z tym samym zapytaniem, została zaproszona na rozmowę kwalifikacyjną. Sprawa trafiła do sądu, a pokrzywdzona kobieta otrzymała odszkodowanie w wysokości 870 euro (Raport EUMC). Raport zawiera jeszcze kilka podobnych przykładów dyskryminacji w innych krajach.

Jeszcze boleśniejsze symptomy braku integracji społecznej w krajach UE zawiera końcowa część raportu podająca statystyki dotyczące liczby przestępstw o podłożu rasowym. Przykładowo, największa liczba przestępstw w 2005 roku popełnionych w analizowanych krajach, miała miejsce w Anglii oraz Walii (połączonych w tej statystyce) i wynosiła 57 902. Na drugim miejscu plasowały się Niemcy z liczbą 15914 przestępstw. Kolejne państwa o dużej, lecz zdecydowanie niższej niż poprzednie kraje liczbie przestępstw na tle rasowym to Szwecja i Szkocja. W innych krajach na szczęście liczby przestępstw są zdecydowanie niższe. W Polsce na przykład w 2005 roku było ich 172. Warto jednak zwrócić uwagę na liczbę osób należących do mniejszości narodowych w poszczególnych krajach. W Niemczech jest ich 7,49 mln na 82 mln ludności, w Wielkiej Brytanii 2,4 mln na 55 mln mieszkańców, a w Polsce na 38 mln mieszkańców w spisie powszechnym w 2002 roku inną niż polska narodowość zadeklarowało niecałe 0,5 mln osób (Janusz 2006). Różnice w liczebności grup mniejszościowych i ich stosunku do liczby ludności kraju są zatem zdecydowane. Na szczególną uwagę zasługuje wśród wymienionych krajów Słowacja. Nasz południowy sąsiad, w którym liczba mniejszości sięga 15\% ludności, zanotowała jedynie 121 przestępstw o podłożu dyskryminacji, co w porównaniu z pozostałymi krajami uwzględnionymi w statystykach jest wynikiem bardzo poprawnym.

Tab. 1. Zmiany liczby przestępstw o podłożu rasowym w latach 2000-2005 w wybranych państwach europejskich

\begin{tabular}{|c|l|c|c|c|c|c|c|}
\hline Lp. & \multicolumn{1}{|c|}{ Państwo } & $\mathbf{2 0 0 0}$ & $\mathbf{2 0 0 1}$ & $\mathbf{2 0 0 2}$ & $\mathbf{2 0 0 3}$ & $\mathbf{2 0 0 4}$ & $\mathbf{2 0 0 5}$ \\
\hline 1 & Czechy & 363 & 452 & 473 & 335 & 364 & 253 \\
\hline 2 & Dania & 28 & 116 & 68 & 52 & 36 & 85 \\
\hline 3 & Niemcy & - & 14725 & 12933 & 11576 & 12553 & 15914 \\
\hline 4 & Francja & 903 & 424 & 1317 & 833 & 1574 & 979 \\
\hline 5 & Irlandia & 72 & 42 & 100 & 62 & 84 & 94 \\
\hline 6 & Austria & 450 & 528 & 465 & 436 & 322 & 406 \\
\hline 7 & Polska & 215 & 103 & 94 & 111 & 113 & 172 \\
\hline 8 & Słowacja & 35 & 40 & 109 & 119 & 79 & 121 \\
\hline 9 & Finlandia & 495 & 448 & 364 & 522 & 558 & 669 \\
\hline 10 & Szwecja & 2703 & 2785 & 2391 & 2436 & 2414 & 2383 \\
\hline 11 & Anglia i Walia & 47829 & 53060 & 54858 & 49340 & 54286 & 57902 \\
\hline 12 & Szkocja & - & - & 1699 & 2673 & 3097 & 3856 \\
\hline
\end{tabular}

Źródło: opracowanie własne na podstawie: Report on racism and xenophobia in the member states of the UE, http://infoportal.fra.europa.eu/InfoPortal/publicationsFrontEndAccess.do?id=11016

W stosunku do liczby przestępstw popełnionych na tle rasowym w roku 2000, liczba przestępstw w roku 2005 zmieniała się różnie w badanych krajach. Do krajów, wśród których 
uległa ona spadkowi, zaliczyć można: Czechy, Austrię, Polskę i Szwecję. Największy stosunkowy postęp poczyniły w tej dziedzinie Czechy. W pozostałych krajach w latach 2000-2005 liczba przestępstw o podłożu dyskryminacyjnym wzrosła. Największy wzrost zanotowano w Słowacji (prawie 3,5-krotny) i w Danii (3-krotny). Niestety tendencje dla liczby przestępstw dyskryminacyjnych są zatem bardzo niekorzystne, a niewielka liczba przestępstw tego typu nie jest faktem zadowalającym ze względu na dużą dynamikę ich wzrostu w ciągu zaledwie pięciu badanych lat.

\section{Przyczyny dyskryminacji i trudności z integracją narodów na przykładzie Romów na polskim rynku pracy}

Współcześnie najliczniejszą mniejszością w Europie jest mniejszość romska. Romowie rozsiani są po wszystkich krajach Unii Europejskiej i liczą dziś około $8 \mathrm{mln}$. Na ich problemy w adaptacji w społeczeństwach krajów przyjmujących zwraca szczególną uwagę również wspomniany wcześniej raport EUMC. Romowie są problematyczną grupą w większości europejskich krajów, pomimo znacznej pomocy, jaka jest im udzielana w szczególności w dziedzinie edukacji i zatrudnienia.

We wcześniejszych rozważaniach autorzy zwracali silnie uwagę na konieczność tolerancji wobec mniejszości i wskazywali krytyczne uwagi wobec niektórych, negatywnych w skutkach działań rządów państw Unii Europejskiej, od sfery ignorancji w zbieraniu danych statystycznych, przez dysproporcje na rynku pracy, aż po przestępstwa o podłożu dyskryminacyjnym. Warto jednak przyjrzeć się również działalności samych mniejszości w celu stwierdzenia, czy aby na pewno wina leży tylko po stronie nietolerancyjnych Europejczyków.

Badania nad rządowymi programami pomocy Romom w Polsce wyraźnie wskazują, że wina złej sytuacji Romów na rynku pracy w sferze socjalnej i edukacyjnej w większej części leży po stronie Romów, aniżeli po stronie państwa polskiego. W 2001 roku ruszył w naszym kraju Pilotażowy Program Rzqdowy na rzecz społeczności romskiej w województwie małopolskim na lata 2001-2003, który stał się podstawą do stworzenia wieloletniego ogólnopolskiego Rzadowego Programu na rzecz społeczności romskiej w Polsce, wprowadzonego w 2004 roku, a którego funkcjonowanie dalej przewidziano do 2013 roku. Program ma na celu pomoc ludności romskiej w dziedzinie edukacji, podnoszenia wiedzy ogólnej i zdobywania kwalifikacji zawodowych, zmiany stosunku do edukacji i pracy oraz ogólne działania mające na celu polepszenie sytuacji bytowej Romów w Polsce.

W 2008 roku do dyspozycji realizujących program było dziesięć milionów złotych. Pomimo rzeczywistego zapału twórców i realizatorów programu i kilku lat doświadczeń w czasie jego działania, skutki społeczne wśród mniejszości romskiej nadal nie są znaczące.

Odwołując się do poprzednio analizowanych danych o stosunku stopy bezrobocia wśród rodzimych mieszkańców wybranych krajów europejskich do stopy bezrobocia wśród mniejszości je zamieszkujących, należy stwierdzić, że porównanie to dla polskich Romów wypada wyjątkowo źle. Zarówno w roku 2007, jak i w 2008 w województwach mazowieckim i kujawsko-pomorskim stopa bezrobocia wśród Romów wynosiła 100\%. Niewiele lepsza sytuacja, gdzie stopa bezrobocia przekraczała 90\%, występowała w 2008 roku w województwach: łódzkim, lubelskim, podlaskim, świętokrzyskim, lubuskim, dolnośląskim i warmińsko-mazurskim. W województwach: śląskim, podkarpackim i wielkopolskim nie zebrano na ten temat danych. Pozytywnie na tle innych województw wyróżniają się województwa: opolskie $(45,7 \%)$ i pomorskie (60\%), których wyniki i tak sąjednak dalekie od oczekiwań. Bardzo duża jest również dysproporcja pomiędzy kilkukrotnie mniejszym bezrobociem wśród ludności ogółem a bardzo wysokim bezrobociem wśród Romów. Jest ono nawet około dziesięciokrotnie wyższe 
w województwach: łódzkim, mazowieckim, małopolskim i podlaskim. Podobne, bardzo słabe efekty, przynoszą również pozarządowe inicjatywy lokalne, a także działania prywatnych instytucji. Tak było w wypadku Fundacji miasta Krakowa, która zorganizowała zatrudnienie grup Romów przy pracach związanych z rewitalizacją obiektów poprzemysłowych dawnego kamieniołomu Liban w Krakowie-Podgórzu, jak również w wypadku powstania romskiej restauracji czy też romskiej firmy remontowo-budowlanej w Tarnowie (Paszko, Sułkowski, Zawicki 2007).

Tab. 2. Stopa bezrobocia wśród Romów i mieszkańców ogółem w województwach Polski w 2008 roku

\begin{tabular}{|c|l|c|c|c|c|}
\hline \multirow{2}{*}{ Lp. } & \multirow{2}{*}{ Województwo } & \multicolumn{4}{|c|}{ Stopa bezrobocia (\%) } \\
\cline { 3 - 6 } & & \multicolumn{2}{|c|}{$\mathbf{2 0 0 7}$} & \multicolumn{2}{c|}{$\mathbf{2 0 0 8}$} \\
\cline { 3 - 6 } & & ogólem & wśród Romów & ogólem & wśród Romów \\
\hline 1 & \multirow{2}{*}{ Lódzkie } & 11,2 & 82,7 & 9,2 & 98,0 \\
\hline 2 & Mazowieckie & 9,0 & 100,0 & 7,3 & 100,0 \\
\hline 3 & Małopolskie & 8,7 & 90,9 & 7,6 & 90,0 \\
\hline 4 & Śląskie & 9,2 & 94,0 & 6,9 & b.d. \\
\hline 5 & Lubelskie & 13,0 & 98,0 & 11,3 & 94,0 \\
\hline 6 & Podkarpackie & 14,2 & b.d & 13,1 & b.d \\
\hline 7 & Podlaskie & 10,4 & 64,2 & 9,8 & 98,0 \\
\hline 8 & Świętokrzyskie & 14,9 & 93,2 & 13,9 & 95,0 \\
\hline 9 & Lubuskie & 14,0 & 95,5 & 12,4 & 95,5 \\
\hline 10 & Wielkopolskie & 7,8 & b.d. & 6,4 & b.d. \\
\hline 11 & Zachodniopomorskie & 16,4 & 84,5 & 13,4 & 82,0 \\
\hline 12 & Dolnośląskie & 11,4 & 99,5 & 10,2 & 96,0 \\
\hline 13 & Opolskie & 11,9 & 32,7 & 9,9 & 45,7 \\
\hline 14 & Kujawsko-pomorskie & 14,9 & 100,0 & 13,4 & 100,0 \\
\hline 15 & Pomorskie & 10,7 & 60,0 & 8,4 & 60,0 \\
\hline 16 & Warmińsko-mazurskie & 18,7 & 99,9 & 16,8 & 98,0 \\
\hline
\end{tabular}

Źródło: opracowanie własne na podstawie danych GUS i Sprawozdania z realizacji Programu na rzecz społeczności romskiej w Polsce w 2008 roku.

Przyczyną tak słabej skuteczności ze strony Programu... i innych inicjatyw jest postawa Romów wobec nauki i edukacji. Romowie mają negatywny stosunek do pracy, uważając ją za zbyt czasochłonny, nudny i mało efektywny sposób zdobywania pieniędzy (Paszko 2007). Co gorsza, nie upatrują oni w edukacji sposobu na zapewnienie sobie lepszej pracy w przyszłości, często nie widząc jej sensu w ogóle. „Prawdy” te, przekazywane przez rodziców dzieciom, jako element zasad życiowych przestrzeganego przez Romów tradycyjnie kodeksu romanipen, głęboko tkwią w umysłach młodych ludzi i sprawiają, że bezrobocie w tej grupie społecznej staje się dziedziczne. W Polsce co trzeci badany Rom nie ma ukończonej szkoły podstawowej, a zaledwie $0,8 \%$ badanej populacji posiada wykształcenie wyższe (Paszko, Sułkowski, Zawicki 2007). Pocieszająca jest postawa romskich autorytetów, które podkreślają konieczność 
edukacji, poprawy sytuacji mieszkaniowej oraz postawy wobec pracy, dając przykład poprzez podejmowanie stałej pracy.

Podobne wyniki badań wśród austriackich Romów uzyskał Fridrich (2007), pokazując niewielkie zaangażowanie społeczne i zawodowe mniejszości romskiej na przykładzie Oberwart przy niezwykłym zaangażowaniu austriackich władz lokalnych, Caritasu i władz federalnych w Wiedniu w poprawę warunków życia Romów. Optymistyczne jest to, że postawa romskich autorytetów w Austrii zaczyna przynosić pozytywne skutki. Coraz więcej młodzieży romskiej w Austrii kończy nie tylko Hauptschule, ale i gimnazja, a nawet zaczyna studiować.

Problemem mniejszości narodowych zaczynają zajmować się również ekonomiści, poszukując najlepszych ekonomicznych instrumentów dla wsparcia tej społeczności. Wśród nich do najlepszych zaliczają się instrumenty mikrofinansowe. Zalicza się do nich: pożyczki, ubezpieczenia, wkłady oszczędnościowe, usługi transferowe, kredyty i tzw. mikrokredyty (szczególnie ważne dla wspierania drobnej przedsiębiorczości jako zwiększenie kapitału początkowego dla małych działalności gospodarczych) i inne usługi finansowe (Paszko, Sułkowski, Zawicki 2007). Jak jednak pokazuje doświadczenie, koniecznym warunkiem pomocy tych instrumentów finansowych jest wcześniejsza edukacja, dokształcenie, zapoznanie z podstawowymi zasadami prowadzenia własnej firmy. Bez wiedzy, doraźna pomoc finansowa nie poprawia sytuacji tej grupy społecznej i nie kształtuje w niej postawy przedsiębiorczej.

\section{Wnioski}

Proces integracji europejskiej odbywa się na trzech płaszczyznach: gospodarczej, politycznej oraz społecznej. Autorzy artykułu za najważniejszą uznali integrację społeczną, gdyż stanowi ona podstawę przyszłości funkcjonowania Unii Europejskiej, tworząc nową tożsamość wśród jej obywateli - tożsamość europejską, silniejszą od związków gospodarczych i politycznych. Społeczność europejska o takiej tożsamości będzie miała charakter społeczeństwa obywatelskiego, składającego się nie z państw, lecz z narodów, zachowując ich różnorodność i bogactwo. Odległość, która dzieli współczesnych Europejczyków od stania się takim właśnie społeczeństwem, jest bardzo trudna do określenia, gdyż jest to dystans istniejący w świadomości jednostek. Autorzy jako wymierny sposób oceny owego dystansu wybrali dane dotyczące dyskryminacji mniejszości narodowych i etnicznych, a także umiejętności ich funkcjonowania na rynku pracy. Na podstawie danych statystycznych można wnioskować, że wina słabej integracji mniejszości ze społeczeństwami jest obopólna. Z jednej strony należy kłaść nacisk na organizację pomocy mniejszościom szczególnie na rynku pracy i w sferze edukacji, na którym to polu w krajach UE pozostaje jeszcze wiele do zrobienia, a także silnie walczyć z uprzedzeniami i dyskryminacją. $Z$ drugiej zaś strony przedstawiciele mniejszości w poszanowaniu dobra wspólnego, jakim jest społeczeństwo, którego sami są częścią, winni wykazywać minimum zainteresowania i chęci poprawy własnej sytuacji poprzez zaangażowanie w edukację i legalną pracę. W ocenie autorów, powstanie tożsamości europejskiej, jaka jest niejako konsekwencją integracji społecznej, jest możliwe i choć bardzo odległe, to warte wspólnego wysiłku. 


\section{Literatura}

1. Chodubski A., 2006, Mniejszości narodowe a globalna społeczność obywatelska [w:] Mniejszości narodowe i etniczne w procesach transformacji oraz integracji, pod red. E. Michalik i H. Chałupczaka, Wydawnictwo Uniwersytetu Marii Curie- Skłodowskiej, Lublin.

2. Fridrich C. (ed.), 2007, From the Margin to the Centre-Capturing the Perspectives of Young People from European Minority Groups, Drava Verlag Klagenfurt.

3. Fridrich C., 2007, Zrozumienie właczania i wyłaczania mniejszości ze społeczno-geograficznego punktu widzenia [w:] Wybrane problemy edukacyjne i kulturowe niektórych mniejszości narodowych i etnicznych w Polsce i Europie pod red. W. Osucha, Geoinfo, Kraków.

4. Halfmann J., 2006, Tożsamości narodowe i wielokulturowość w Europie [w:] Wspótczesna Europa w procesie zmian. Wybrane problemy, pod red. J. Polakowskiej-Kujawy, Centrum Doradztwa i Informacji Difin, Warszawa.

5. Siewierski J., 2006, Źródła tożsamości europejskiej [w:] Współczesna Europa w procesie zmian. Wybrane problemy, pod red. J. Polakowskiej-Kujawy, Centrum Doradztwa i Informacji Difin, Warszawa.

6. Janusz G., 2006, Statystyczny obraz mniejszości narodowych we wspótczesnej Europie [w:] Mniejszości narodowe i etniczne w procesach transformacji oraz integracji, pod red. E. Michalik i H. Chałupczaka, Wydawnictwo Uniwersytetu Marii Curie-Skłodowskiej, Lublin.

7. Niżnik J., 2006, Integracja europejska $w$ dyskursie politycznym [w:] Współczesna Europa w procesie zmian. Wybrane problemy, pod red. J. Polakowskiej-Kujawy, Centrum Doradztwa i Informacji Difin, Warszawa.

8. Paszko A., 2007, Romowie i polskie doświadczenie wolnego rynku [w:] Romowie w Polsce i Europie, pod red. P. Borka, Wydawnictwo Naukowe Akademii Pedagogicznej, Kraków, s. 204-216.

9. Paszko A., Sułkowski R., Zawicki M. (red.), 2007, Romowie na rynku pracy, Małopolska Szkoła Administracji Publicznej Akademii Ekonomicznej w Krakowie, Kraków.

10. Porębski A., 2006, Problematyka autochtonicznych grup etnicznych we wspótczesnej Europie [w:] Mniejszości narodowe i etniczne w procesach transformacji oraz integracji, pod red. E. Michalik i H. Chałupczaka, Wydawnictwo Uniwersytetu Marii Curie-Skłodowskiej, Lublin.

11. Rabczańska A.J., 2006, Instytucjonalizacja ochrony mniejszości narodowych i etnicznych na poziomie międzynarodowym [w:] Mniejszości narodowe i etniczne $w$ procesach transformacji oraz integracji, pod red. E. Michalik i H. Chałupczaka, Wydawnictwo Uniwersytetu Marii Curie-Skłodowskiej, Lublin.

12. http://infoportal.fra.europa.eu/InfoPortal/publicationsFrontEndAccess.do?id=11016

13. http://www.stat.gov.pl

14. http://www.mswia.gov.pl/portal/pl/366/7679/Sprawozdanie_z_realizacji_Programu_na_rzecz_spolecznosci_romskiej_w_Polsce_za_ro.html 


\section{Selected Problems of Ethnic Minorities Versus the Idea of Civic Society in European integration - Theoretical Considerations and Practice}

This article presents a socio-economic problems of national minorities in certain aspects of the processes of European integration. In European countries, as well as in Poland, the unemployment rate among ethnic minority groups is very high, compared to the general public. This problem affects particularly the Roma minority, because of cultural difference and the inability to find themselves in the current economic situation, which causes progressive social marginalization. High racist delinquency, as well as an increase in labor market discrimination against minorities, in various countries of the European Union, are not conducive to the processes of social and citizen integration of those groups. The reason, as well as the effect of such situation is the very low level of education of Roma, not only in Poland but also in other European countries.

Authors reckon, that one of the conditions of informative society's growth is necessity to support their enterprising posture. Following this thesis, the authors think, that supporting lower developed groups, which don't keep up with actual tempo of economic growth is necessary to minimalize the social-economic marginalization of these groups and to limit social anxienties and clashes.

Authors, on the example of Roma ethic minority group characterized the problems of these groups on work market, ways of fighting with them and showed the perspectives of progress of these groups in future by building enterprising postures.

It seems that the measure of a progressive European social integration should be an appropriate relationship to national and ethnic minorities in EU member countries, free from social and occupational, and discrimination on labor market, which does not seem easy in a market economy based on knowledge. 